\title{
Biochemical identification of Lactobacillus piscicola strains from France and Belgium
}

\author{
C. Michel, B. Faivre \& B. Kerouault \\ Laboratoire d'Ichtyopathologie, INRA, Groupe de Laboratoires de Pathologie Animale, route de Thiverval, F-78850 \\ Thiverval-Grignon, France
}

\begin{abstract}
Of 8 strains of Lactobacillus isolated in France and Belgium since 1977, 7 were found to display the general characteristics and fermentation pattern of $L$. piscicola. This recently described species was initially observed in the Pacific Northwest region of North America where it usually caused a chronic infection ('pseudo-kidney disease') in yearling or older trout and salmon. The present results show, however, that very young salmonids and carp may also be affected and confirm an earlier report that the organism also occurs in western Europe. The organism shows low virulence, and difficulty was experienced in demonstrating its pathogenicity. Nevertheless, L. piscicola appears to be a genuine pathogen even though its significance to fish culture remains to be fully evaluated.
\end{abstract}

\section{INTRODUCTION}

Isolation of species of Lactobacillus from diseased or healthy fish is commonplace in routine fish diagnostics. These microorganisms were considered part of the normal fish gut microflora and were thought to be devoid of any pathogenic significance until Ross \& Toth (1974) reported a chronic disease of adult salmonids associated with a member of this genus. Initially, this disease, now referred to as 'pseudo-kidney disease', had probably often been mistaken for BKD (due to Renibacterium salmoninarum). Since the recognition of the causative Lactobacillus it has been regularly observed among fish of the Pacific Northwest region of America (Hiu et al. 1984). However, occasional observations in other parts of the world (Austin 1980, Cone 1982, Herman et al. 1985) suggest that this or very similar strains of fish-pathogenic lactobacilli may have a broader geographical distribution than previously thought. Hiu et al. (1984) undertook a taxonomic study of strains isolated during the past $15 \mathrm{yr}$, and distinguished a new species, called Lactobacillus piscicola. It is noteworthy that one of their 16 strains originated from Italy. Because similar isolates have been collected from fish in increasing numbers in France since 1977, it was of interest to compare their characteristics to those of $L$. piscicola.

\section{MATERIAL AND METHODS}

The 8 strains studied were isolated from diseased fish sent to Thiverval-Grignon or to other French laboratories for microbiological examination. The host and geographic origin of the isolates are summarized in Table 1. The general characteristics of the isolates were determined according to routine procedures using standard commercial media and reagents supplied by Institut Pasteur Production (IPP). Carbohydrate fermentation was studied in the API $50 \mathrm{CHL}$ System (API System SA). The carbohydrate media were inoculated with bacterial suspensions prepared from cultures in De Man-Rogosa-Sharpe (MRS) medium. Incubation was performed at $30^{\circ} \mathrm{C}$ for $3 \mathrm{~d}$.

Antimicrobial sensitivity tests were conducted at $22^{\circ} \mathrm{C}$ in Mueller Hinton medium (MHM) using the agar-diffusion method. Although it has been noted that this method is not suitable for determining minimal inhibitory concentrations of drugs with fishassociated bacteria (Michel \& Bassalert 1982), it was preferred to our dilution system in which the growth of Lactobacillus proved inconsistent. All strains except P09-84 were tested against standard antibiotic disks purchased from IPP. The drugs studied are listed in Table 3. Because the method permits only a crude measure of sensitivity, drugs were considered effica- 
Table 1. Sources of the Lactobacillus strains used in the study

\begin{tabular}{|c|c|c|c|c|}
\hline Strains & Collection & Host fish & Origin & Pathogenicity \\
\hline $169-772$ & Grignon & $\begin{array}{l}\text { Adult } \\
\text { Salmo trutta }\end{array}$ & $\begin{array}{l}\text { Fish culture } \\
\text { (Nord) }\end{array}$ & Chronic \\
\hline $169-773$ & Grignon & $\begin{array}{l}\text { Adult } \\
\text { S. trutta }\end{array}$ & $\begin{array}{l}\text { Fish culture } \\
\text { (Nord) }\end{array}$ & Chronic \\
\hline A $12-83$ & Maisons-Alfort & $\begin{array}{l}\text { Fry } \\
\text { S. gairdnen }\end{array}$ & $\begin{array}{l}\text { Fish culture } \\
\text { (Charente) }\end{array}$ & Kidney granuloma \\
\hline $38-83$ & Grignon & $\begin{array}{l}\text { Fingerling } \\
\text { S. trutta }\end{array}$ & $\begin{array}{l}\text { Fish culture } \\
\text { (Belgium) }\end{array}$ & Chronic \\
\hline P 09-84 & Grignon & Brachydanio rerio & $\begin{array}{l}\text { Ornamental aquarium at } \\
\text { Grignon (Ile de France) }\end{array}$ & ? (Dying fish) \\
\hline $20-853$ & Grignon & $\begin{array}{l}\text { Adult } \\
\text { S. trutta }\end{array}$ & $\begin{array}{l}\text { Fish culture } \\
\text { (Ile de France) }\end{array}$ & $\begin{array}{l}\text { Chronic (other bacteria } \\
\text { also present) }\end{array}$ \\
\hline R 840 & D.S.V. Jura & $\begin{array}{l}\text { Adult } \\
\text { Cyprinus carpio }\end{array}$ & $\begin{array}{l}\text { Pond } \\
\text { (Dombes) }\end{array}$ & $?$ \\
\hline R 919 & D.S.V. Jura & $\begin{array}{l}\text { Fingerling } \\
\text { S. trutta }\end{array}$ & $\begin{array}{l}\text { Fish culture } \\
\text { (Jura) }\end{array}$ & $?$ \\
\hline
\end{tabular}

cious only when they resulted in clear-cut zones of inhibition.

Experimental infections were carried out to assess the pathogenicity of 3 strains (A 12-83, 38-83 and 20-85.3). Trypticase soy broth (TSB) cultures were harvested at $24 \mathrm{~h}$ and diluted in saline to obtain $10^{6}$ to $10^{7}$ bacterial cells $\mathrm{ml}^{-1}$. Ten $8 \mathrm{~g}$ rainbow trout Salmo gairdneri, previously acclimatized at $15^{\circ} \mathrm{C}$, were anaesthetized in MS $222\left(50 \mathrm{mg} \mathrm{l}^{-1}\right)$ and injected intraperitoneally with $0.1 \mathrm{ml}$ of the test strain suspension. Control fish received a similar injection of physiological saline. Daily mortalities were recorded over a 3 wk period, and all dead fish were examined bacteriologically.

\section{RESULTS}

All strains shared the same general characteristics: they were non-motile, non-sporogeneous, Gram-positive bacilli that produced small white colonies on tryptic soy agar. They grew at $15^{\circ} \mathrm{C}$ and at $37^{\circ} \mathrm{C}$, but not at $45^{\circ} \mathrm{C}$. They were all facultative anaerobes and showed no oxidase or catalase activity. Glucose was fermented without production of gas. Nitrates were not reduced. Urease and hydrogen sulfide reactions were negative, but arginine was hydrolysed. Voges-Proskauer and ONPG reactions were usually positive. All of these features were in accordance with those expected for Lactobacillus piscicola.

The carbohydrate fermentation pattern is given in Table 2, and is compared with the results obtained by other workers. Except for Strain P 09-84, which was isolated from an ornamental fish, the characteristics of all our isolates were consistent with the standard description for Lactobacillus piscicola. Some minor discrepancies occurred but are easily explained by differences in the conditions of reading: Hiu et al. (1984) did not incubate their cultures beyond $48 \mathrm{~h}$ and thus probably missed the reactions with mannitol, methyl-d-mannoside, and starch (these were delayed reactions). Also, it must be noted that galactose, methyl-glucoside, inulin, and melesitose often yielded weakly positive or doubtful reactions. Difficulties in interpreting such reactions often lead to contradictory readings.

The drug sensitivity results are shown in Table 3 . It appeared that some drugs like the penicillin derivatives (ampicillin, ticarcillin), tetracycline, chloramphenicol, erythromycin and the nitrofurans all inhibited the Lactobacillus strains. On the other hand, the aminoglycosides, colistin, polymyxin $B$, sulphonamides, quinolines, and to a lesser degree the cephalosporins were not inhibitory.

Infection trials resulted in low mortalities. Strain 3883, perhaps due to long-term culture on artificial media, failed to kill any fish. Strain A 12-83 killed 2 fish but was only reisolated from one of them. Strain 20-85 killed 3 fish and was reisolated from all 3 fish. In the last case, the trout died within 4 to $6 \mathrm{~d}$ of challenge and showed an acute form of infection quite different from that which occurred under natural conditions. Although the virulence was low, the Koch's postulates were fulfilled.

\section{DISCUSSION AND CONCLUSIONS}

Hiu et al. (1984) performed their taxonomic work with 16 strains originating from Oregon and an additional strain originating from Italy. This permitted them to conclude that Lactobacillus piscicola occurred 
Table 2. Lactobacillus spp. Reactions obtained with the present Lactobacillus strains using API 50 CHL systems incubated for $72 \mathrm{~h}$ at $30^{\circ} \mathrm{C}$ compared with those reported for Lactobacillus strains by other workers (type description of $L$. piscicola, after Hiu et al. 1984 , read at $48 \mathrm{~h}$ )

\begin{tabular}{|c|c|c|c|c|c|c|c|c|c|c|c|}
\hline Sugars & 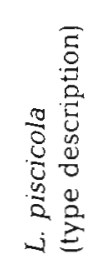 & 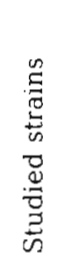 & 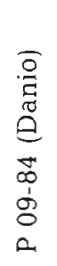 & 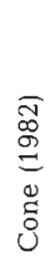 & 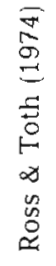 & Sugars & 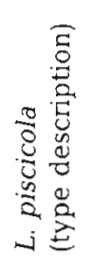 & 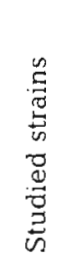 & 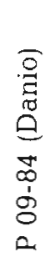 & 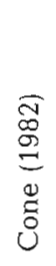 & $\begin{array}{l}\vec{F} \\
\bar{\sigma} \\
\stackrel{0}{\Xi} \\
5 \\
5 \\
0 \\
\infty \\
\infty \\
0 \\
0 \\
0\end{array}$ \\
\hline Control & & - & - & & & Esculin & + & + & + & - & + \\
\hline Glycerol & + & + & - & & & Salicin & + & + & + & + & \\
\hline Erythritol & - & - & - & & & Cellobiose & + & + & + & & \\
\hline D-Arabinose & - & - & - & + & & Maltose & + & + & + & + & + \\
\hline L-Arabinose & - & - & - & + & & Lactose & $\mathrm{d}$ & d & + & - & + \\
\hline Ribose & + & + & - & & & Melibiose & $d$ & $\mathrm{~d}$ & - & & \\
\hline D-Xylose & - & - & - & & & Sucrose & + & + & + & + & + \\
\hline L-Xylose & - & - & - & & & Trehalose & + & + & + & & \\
\hline Adonitol & - & - & - & & & Inulin & - & $+{ }^{\bullet}$ & - & & \\
\hline Methyl-xyloside & - & - & - & & & Melesitose & - & $\mathrm{d}^{*}$ & + & & \\
\hline Galactose & $\mathrm{d}$ & $\mathrm{d}^{\cdot}$ & + & & & D-Raffinose & d & d & + & & \\
\hline D-Glucose & + & + & + & + & + & Starch & - & [d] & - & & \\
\hline D-Levulose & + & + & + & & & Glycogen & - & - & - & & \\
\hline D-Mannose & + & + & + & & & Xylitol & & - & - & & \\
\hline L-Sorbose & - & - & - & & & $\beta$-Gentiobiose & & + & - & & \\
\hline Rhamnose & - & - & - & - & & D-Turanose & & $\mathrm{d}^{*}$ & + & & \\
\hline Dulcitol & - & - & - & - & & D-Lyxose & & - & - & & \\
\hline Inositol & - & - & - & - & & D-Tagatose & & - & - & & \\
\hline Mannitol & + & $1+1$ & + & + & + & L-Fucose & & - & - & & \\
\hline Sorbitol & - & - & - & + & & D-Fucose & & - & - & & \\
\hline Methyl-D-mannoside & - & [d] & - & & & D-Arabitol & & - & - & & \\
\hline Methyl-D-glucoside & $\mathrm{d}$ & $\mathrm{d}^{*}$ & - & & & L-Arabitol & & - & - & & \\
\hline N-Acetyl-glucosamine & + & + & t & & & Gluconate & & + & & - & \\
\hline Amydalin & + & + & - & & & 2-keto-gluconate & & - & - & & \\
\hline Arbutine & + & + & + & & & 5-keto-glutonate & & - & - & & \\
\hline
\end{tabular}

in Europe. The present study confirms this conclusion and shows that Lactobacillus infections are more frequent among fish in European trout farms than hitherto thought and that they can also occur in very young fish. The fact that most of the isolates were found in the last $3 \mathrm{yr}$ most likely reflects the increasing interest of investigators. It is worth noting that one of our strains was isolated from a carp collected from the Dombes region, near Lyon, France. Intensive culture of carp is traditional in this area and it can be assumed that rather than being restricted to salmonids, L. piscicola can infect other species of commercially important fish.

Adult fish seem the most susceptible, especially during the spawning season when they are exposed to various stress factors (Cone 1982, Hiu et al. 1984, Herman et al. 1985). Indeed, although very young fish can be affected, most of our observations involved adult fish (Table 1). Susceptibility to the pathogenic action of Lactobacillus piscicola, which showed low virulence in the laboratory, must be largely stress mediated. The organism frequently occurs in association with secondary invaders (which sometimes hampers the isolation of the Lactobacillus). It is clear that further work will be needed before the importance of Lactobacillus can be accurately assessed.

Hiu et al. (1984) indicated that the strains studied by Cone (1982) were different from Lactobacillus piscicola. A dying Brachydanio rerio examined in the present study yielded another strain that differed from L. piscicola (Table 2). It therefore appears that other species of Lactobacillus are common in fish but their interrelations remain to be determined. The pattern of carbohydrate fermentation provides a reliable means for recognizing $L$. piscicola but this requires observation of strain growth on MRS medium over extended periods. Undoubtedly, rapid and more convenient diagnostic methods will be necessary if it appears that several species of Lactobacillus are harboured by fish. 
Table 3. Lactobacillus piscicola. Sensitivity of 7 strains isolated from fish to various antimicrobial drugs. R: strongly resistant (inhibition); r: moderately resistant; $S$ : sensitive (inhibition diameters correspond to the upper critical values suggested by the disk-supplier)

\begin{tabular}{|c|c|c|c|c|c|c|}
\hline \multirow[t]{2}{*}{ Drug } & \multirow{2}{*}{$\begin{array}{l}\mu g \text { antibiotic } \\
\text { disk }^{-1}\end{array}$} & \multirow{2}{*}{$\begin{array}{l}\text { Upper critical value } \\
\text { (diameter in mm) }\end{array}$} & \multirow{2}{*}{$\begin{array}{l}\text { Number of } \\
\text { strains tested }\end{array}$} & \multicolumn{3}{|c|}{ Number of strains with indicated sensitivity } \\
\hline & & & & $\mathrm{R}$ & I & $\mathrm{S}$ \\
\hline Ampicillin & 10 & 17 & 7 & 0 & 1 & 6 \\
\hline Ticarcillin & 75 & 12 & 7 & 0 & 0 & 7 \\
\hline Cefalotin & 30 & 18 & 7 & 1 & 2 & 4 \\
\hline Cefalexin & 30 & 18 & 7 & 2 & 5 & 0 \\
\hline Streptomycin & 10 & 14 & 7 & 7 & 0 & 0 \\
\hline Kanamycin & 30 & 17 & 7 & 6 & 1 & 0 \\
\hline Gentamycin & 15 & 16 & 4 & 3 & 1 & 0 \\
\hline Tetracycline & 30 & 19 & 7 & 0 & 0 & 7 \\
\hline Chloramphenicol & 30 & 23 & 7 & 0 & 0 & 7 \\
\hline Erythromycin & 15 & 22 & 7 & 0 & 0 & 7 \\
\hline Colistin & 50 & 15 & 5 & 5 & 0 & 0 \\
\hline Polymyxin B & 300 & 15 & 7 & 7 & 0 & 0 \\
\hline Nitrofurans & 300 & 15 & 7 & 0 & 0 & 7 \\
\hline Sulphonamides & 200 & 15 & 7 & 7 & 0 & 0 \\
\hline Nalidixic acid & 30 & 20 & 7 & 7 & 0 & 0 \\
\hline Flumequine & 30 & 23 & 6 & 6 & 0 & 0 \\
\hline
\end{tabular}

and if epizootiological studies are planned to clarify the true status and the economic significance of these bacteria to fish farming.

Acknowledgements. We are indebted to Dr. Syberg (Tavier, Belgium), Dr. Morand (Lons-Le-Saunier) and Anne-Marie Hattenberger-Baudouy (Alfort), for providing some of the strains used in the study. The work was supported in part by the Conseil Supérieur de la Pêche, grant no. 2562 B.

\section{LITERATURE CITED}

Austin, B. (1980). Characterization of the causal agents of bacterial kidney disease. In: Ahne, W. (ed.) Fish diseases. 3rd COPRAQ Session. Springer Verlag, Berlin, p. 147-153
Cone, D. K. (1982). A Lactobacillus sp. from diseased female rainbow trout, Salmo gairdneri Richardson, in Newfoundland Canada. J. Fish Dis. 5: 479-485

Herman, R. L., McAllister, K., Bullock, G. L., Shotts, E. B., Jr. (1985). Postspawning mortalities of rainbow trout (Salmo gairdneri) associated with Lactobacillus. J. Wildl. Dis. 21: 358-360

Hiu, S. F., Holt, R. A., Sriranganathan, N., Seidler, R. J., Fryer, J. L. (1984). Lactobacillus piscicola, a new species from Salmonid fish. Int. J. syst. Bacteriol. 34: 393-400

Michel, C., Bassalert, J. F. (1982). Influence de la température sur les résultats de l'antibiogramme pratiqué par la méthode de diffusion en Ichtyopathologie. Ann. Rech. Vet. 13: $245-250$

Ross, A. J., Toth, R. J. (1974), Lactobacillus. A new fish pathogen? Progve Fish Cult. 36: 191

Responsible Subject Editor: Dr. T. Evelyn; accepted for printing on December 16, 1986 